\title{
ANALISIS PRAKTEK JUAL BELI DROPSHIPPING DALAM PERSPEKTIF EKONOMI ISLAM
}

\author{
RISVAN HADI \\ BPRS PUDUARTA INSANI \\ hadi.risvan.@yahoo.com
}

\begin{abstract}
In this Dropshipping system there are three related actors they are buyers, sellers (goods owners) and Dropshipper. The series of product sales through the Dropshipping system is when a customer has paid for a product to Dropshipper. Then Dropshipper pays the seller while sending details of the products ordered by the customers. Then the owner of the item will send the product directly ordered by the customer. This research aims to explain the scheme of buying and selling online with the Dropshipping system and analyzing online buying and selling with the Dropshipping system in the perspective of Islamic Economics. This research is a qualitative research. The results of this research conclude that Dropshipping is allowed in the perspective of Islamic Economics by using syirkah contracts, that is syirkah wujuh and simsarah (broker /agent). Both forms of this transaction can legalize Dropshipping buying and selling practices as long as there is no element of gharar / fraud. This Dropshipping practice is in accordance with Maqashid Syariah which will give a pattern of rational and substantial thinking in looking at forms of transactions to respond the growing business that continues to grow.
\end{abstract}

Keywords: Dropshipping, Syirkah wujuh, Simsarah, Gharar.

\begin{abstract}
Abstrak
Dalam sistem Dropshipping ini ada tiga pelaku yang terkait yakni pembeli, penjual (pemilik barang) dan Dropshipper. Rangkaian penjualan produk melalui sistem Dropshipping adalah ketika pelanggan sudah membayar untuk sebuah produk kepada Dropshipper. Kemudian Dropshipper membayar kepada penjual sekaligus mengirimkan rincian produk yang dipesan oleh para pelanggan. Selanjutnya pemilik barang akan mengirimkan langsung produk yang dipesan pelanggan. Penelitian ini bertujuan untuk menjelaskan skema dari jual beli online dengan sistem Dropshipping dan menganalisis jual beli online dengan sistem Dropshipping dalam perspektif Ekonomi Islam. Penelitian ini merupakan penelitian kualitatif. Hasil penelitian ini menyimpulkan bahwa jual beli Dropshipping dibolehkan dalam perspektif Ekonomi Islam dengan menggunakan akad syirkah, yaitu syirkah wujuh dan simsarah (makelar/agen). Kedua bentuk transaksi ini dapat melegalisasi praktek jual beli Dropshipping selama tidak terdapat unsur gharar/penipuan. Praktek Dropshipping ini sesuai dengan Maqashid Syariah yang akan memberikan pola pemikiran yang rasional dan substansial dalam memandang bentuk-bentuk transaksi untuk merespon kemajuan bisnis yang terus berkembang.
\end{abstract}

Kata Kunci : Dropshipping, Syirkah wujuh, Simsarah, Gharar. 


\section{Pendahuluan}

Dalam kajian ekonomi Islam dan keuangan kontemporer, banyaknya muncul persoalan-persoalan persaingan bisnis yang merupakan salah satu pemicu perubahan yang harus diperhitungkan, dengan munculnya berbagai produk yang semakin beragam, menuntut para produsen untuk terus bersaing. Para produsen tentunya akan selalu berinovasi dalam menghadapi persaingan dan pesaing berupaya menjadi yang terbaik, yaitu menjalankan bisnisnya dengan produk yang bermutu, harga bersaing dan pelayanan total. ${ }^{1}$

Kegiatan pembelian, jika ditelusuri secara mendalam merupakan salah satu tahap dari keseluruhan proses keputusan pembelian. Proses keputusan pembelian bagi konsumen meliputi beberapa tahap berikut ini: pengenalan masalah, pencarian informasi, evaluasi alernatif, pembelian dan evaluasi proses pembelian. Tentunya tidaklah seluruh tahapan tersebut dilalui atau dilaksanakan oleh konsumen. Keseluruhan proses tersebut biasanya dilakukan pada situasi dan kondisi tertentu saja, misalnya pada pembelian pertama dan atau pembelian barang-barang yang harga atau nilainya relatif tinggi. Pada dasarnya konsumen akan lebih mudah mengambil keputusan pembelian yang sifatnya pengulangan atau terus menerus terhadap produk yang sama. Apabila faktor-faktor yang mempengaruhinya berubah, tentunya konsumen akan mempertimbangkan kembali dalam keputusan pembeliannya. Ada beberapa keputusan yang menjadi pertimbangan bagi konsumen yaitu mengenai: jenis produk, bentuk produk, merek produk, jumlah produk, waktu pembelian dan cara pembayaran. Setiap merek atas produk dan penjualan suatu perusahaan, memiliki keunikan dan kekhususan tersendiri yang akan membedakannya dengan para pesaing lainnya.

Zaman era globalisasi sekarang ini, tingkat kemajuan di bidang teknologi telah memberikan kemudahan bagi manusia salah satunya dalam bidang perniagaan. Internet telah memberikan berbagai fasilitas bagi penggunanya, salah diantaranya adalah fasilitas sebagai tempat jual beli.

Jumlah online shopper di Indonesia terus meningkat selama beberapa tahun terakhir. Di tahun 2018, jumlah online shopper diperkirakan mencapai 11,9 persen dari total populasi di Indonesia," demikian keterangan tertulis dari 
CupoNation yang diterima Kompas.com pada Jumat (7/9/2018). Public Relations and Communications Manager CupoNation, Olivia Putri, menjelaskan, dari studi internal pihaknya, didapati pertumbuhan pembeli secara online atau online shopper di Indonesia terjadi dalam tiga tahun terakhir. Pada tahun 2016, jumlah pembeli online mencapai 9,6 persen dari jumlah populasi dan meningkat menjadi 10,7 persen pada tahun 2017.

Pertumbuhan jumlah pembeli online ini didukung oleh pendapatan dari pasar e-commerce Indonesia, di mana ada 6,1 miliar dollar AS pada 2016 dan mencapai 7,5 miliar dollar AS untuk tahun 2017. "Tahun ini diperkirakan pendapatan pasar e-commerce bisa mencapai 9,1 miliar dollar AS," tutur Olivia. Data dalam penelitian ini bersumber dari lembaga statistik internasional bernama Statista. "Tahun ini diperkirakan pendapatan pasar e-commerce bisa mencapai 9,1 miliar dollar AS". ${ }^{2}$

Namun secara umum pemanfaatan interrnet masih jauh dari optimal. Terlebih di Indonesia, jangan kaget kalau ada pengusaha Indonesia yang belum pernah bersentuhan dengan komputer apalagi internet. Pengusaha yang bisa tetap bertahan adalah yang berani menghadapi perubahan dengan mengambil keuntungan dari perubahan itu sendiri. ${ }^{3}$

Oleh karena itu, dengan mengoptimalkan salah satu manfaat yang diberikan oleh internet, maka sekarang ini mulai dikenal banyaknya bisnis yang memanfaatkan internet sebagai medianya, yang dikenal sebagai bisnis online. Bisnis online adalah segala kegiatan yang menyangkut kegiatan berbisnis (jual beli) dengan media internet untuk mencapai tujuannya. Bisnis online tidak mengenal ruang dan waktu, dapat dilakukan dimana saja hampir selama 24 jam. Oleh karena itu bisnis dari jual beli online ini seperti tidak ada matinya, dengan pangsa pasar yang luas ditambah lagi dengan berbagai kemudahan didalamnya maka bisnis ini pun menjadi hal yang tentu sangat menggiurkan.

Salah satu alternatif dalam internet marketing yang belakangan ini sedang booming adalah jual beli online dengan menggunakan sistem Dropship. Masalah-masalah yang ditakuti seperti ketiadaan waktu ataupun modal bisa diatasi dengan cara ini. 
234 AT-TAWASSUTH: Jurnal Ekonomi Islam, Volume IV No. 2

Juli - Desember 2019: 231 - 251

Dropshipping merupakan penjualan produk yang memungkinkan Dropshipper menjual barang ke pelanggan dengan bermodalkan foto dari supplier/toko (tanpa harus menyetok barang) dan menjual dengan harga yang ditentukan oleh Dropshipper atau kesepakatan harga bersama antara supplier dengan Dropshipper. ${ }^{4}$

Dropship adalah teknik manajemen rantai pasokan dimana reseller atau retailer (pengecer) tidak memiliki stok barang. Pihak produsen atau grosir sebagai pelaku Dropshipper yang nantinya akan mengirim barang secara langsung pada pelanggan. Keuntungan akan didapat dari selisih antara harga dari grosir dengan dari pengecer.

Jika dilihat secara sekilas, tentu menjadi hal yang agak sulit dimengerti bagi mereka yang baru mengenal istilah tersebut. Namun sesungguhnya, pada praktiknya ini adalah hal yang mudah untuk dilakukan. Gampangnya, Dropshipping adalah menjual barang milik supplier atas seizin supplier kepada pembeli dengan bermodalkan komputer dan koneksi internet.

Dalam sistem Dropship ini ada tiga pelaku yang terkait yakni pembeli, penjual (pemilik barang) dan Dropshipper. Rangkaian penjualan produk melalui sistem Dropship adalah ketika pelanggan sudah membayar untuk sebuah produk kepada Dropshipper. Kemudian Dropshipper membayar kepada penjual sekaligus mengirimkan rincian produk yang dipesan oleh para pelanggan. Selanjutnya pemilik brang akan mengirimkan langsung produk yang dipesan pelanggan.

Melakukan jual beli tentu tidak bisa dilakukan dengan asal, ada aturanaturan yang mengikatnya, apalagi jika jual beli dikaitkan dengan agama, karena dalam melakukan jual beli terdapat dua pihak yang salah satunya tidak boleh merasa dirugikan, jika ada yang merasa dirugikan maka batallah transaksi jual beli tersebut.

Di dalam Islam sendiri jual beli diperkenalkan dalam bidang muamalah. Pengertian muamalah dalam arti luas adalah aturan hukum Allah untuk mengatur manusia dalam kaitannya dengan urusan duniawi dan definisi pengertian muamalah arti sempit adalah aturan-aturan Allah yang mengatur hubungan 
manusia dengan manusia dalam kaitannya dengan cara memperoleh dan mengembangkan harta benda. ${ }^{5}$

Menurut jumhur ulama salah satu yang menjadi rukun dan syarat sah nya jual beli adalah ijab dan qabul, dimana terdapat syarat yang terkait dengan ijab dan qabul ini, yaitu ijab dan qabul ini dilakukan dalam satu majelis dan berarti mengharuskan para pihak untuk saling bertemu. ${ }^{6}$

Jual beli online dengan sistem Dropshipping jika ditinjau menurut fikih muamalah maka ada poin yang dilanggar yakni mengenai kepemilikan barang jualan atau produk yang dijual oleh pelaku Dropship, dimana para pelaku Dropship hanya memasang katalog atau rincian barang di situs atau media sosial yang ia punya sebagai tempat pemasaran namun tidak memiliki barang atau produk yang ia tawarkan. Produk tersebut masih dimiliki oleh para produsen atau supplier, penjual hanya memasarkan di situsnya dengan mendapat keuntungan dari selisih harga antara supplier dengan harga yang ia pasang jika di ibaratkan maka pelaku Dropshipping hampir sama dengan seorang makelar.

Jika ditinjau lebih jauh menurut fikih muamalah, jual beli Dropship ini tidak sesuai dalam yakni benda atau barang yang diperjual belikan adalah "barang tersebut harus milik pribadi". ${ }^{1}$ Sedangkan dalam jual beli sistem Dropship barang yang dijual oleh penjual bukanlah barang milik pribadinya melainkan hanya memasarkan produk milik supplier (grosir). Selain itu jual beli ini dinilai berisiko karena hanya memperlihatkan produk dari gambar saja tanpa melihat langsung.

\section{Bentuk-Bentuk Transaksi Dalam Ekonomi Islam}

Akad Tijarah adalah segala macam perjanjian yang menyangkut for profit transaction. Akad-akad ini dilakukan dengan tujuan mencari keuntungan, karena itu bersifat komersil. Contoh akad tijarah adalah akad-akad investasi, jual beli, dan sewa menyewa. Yang termasuk ke dalam akad tijari yaitu murabahah, salam, istishna, ijarah, dan musyarakah. ${ }^{7}$

\footnotetext{
${ }^{1}$ Rachmat Syafei, Fiqh Muamalah, (Bandung : Pustaka Setia, 2001), h. 79.
} 
Murabahah adalah akad jual beli atas barang tertentu, dimana penjual menyebutkan harga pembelian barang kepada pembeli kemudian menjual kepada pihak pembeli dengan mensyaratkan keuntungan yang diharapkan sesuai jumlah tertentu. Dalam akad Murabahah, penjual menjual barangnya dengan meminta kelebihan atas harga beli dengan harga jual. Perbedaan antara harga beli dan harga jual barang disebut dengan margin keuntungan. ${ }^{8}$

Murabahah adalah akad jual beli atas barang tertentu, dimana penjual menyebutkan harga pembelian barang kepada pembeli kemudian menjual kepada pihak pembeli dengan mensyaratkan keuntungan yang diharapkan sesuai jumlah tertentu. $^{9}$

\section{Dasar Hukum Murabahah}

1. Al-Qur'an

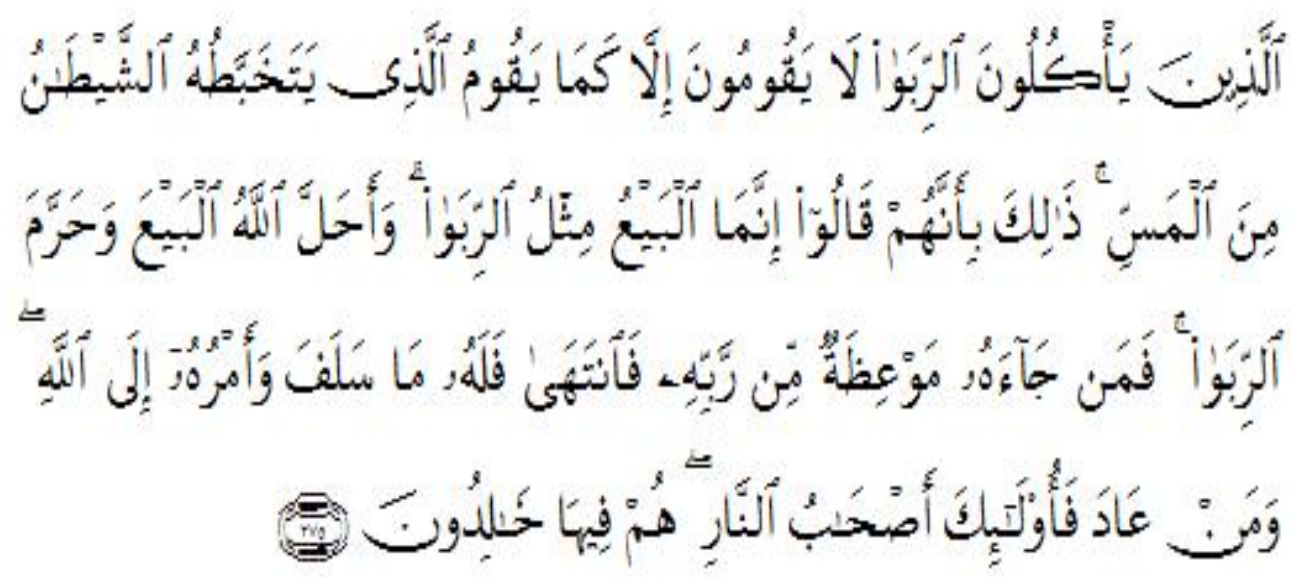

Artinya : orang-orang yang Makan (mengambil) riba tidak dapat berdiri melainkan seperti berdirinya orang yang kemasukan syaitan lantaran (tekanan) penyakit gila. Keadaan mereka yang demikian itu, adalah disebabkan mereka berkata (berpendapat), Sesungguhnya jual beli itu sama dengan riba, Padahal Allah telah menghalalkan jual beli dan mengharamkan riba. orang-orang yang telah sampai kepadanya larangan dari Tuhannya, lalu terus berhenti (dari mengambil riba), Maka baginya apa yang telah diambilnya dahulu (sebelum datang larangan); dan urusannya (terserah) kepada Allah. orang yang kembali (mengambil riba), Maka orang itu adalah penghuni-penghuni neraka; mereka kekal di dalamnya. (al-Baqarah: 275) ${ }^{10}$

2. Hadis

Sebagaimana hadis yang artinya : "Dari Rifaah bin Rafiq, Nabi SAW ditanya tentang usaha yang baik, Nabi menjawab perbuatan seseorang dengan 


\section{Risvan Hadi: Analisis Praktek Jual Beli Dropshipping $\mid 237$}

tangannya dan semua jual beli yang baik". Hadis riwayat Al Bazar dan Hakim. $^{11}$

3. Fatwa Dewan Syariah Nasional Majelis Ulama Indonesia No.04/DSNMUI/IV/2000, tentang MURABAHAH.

Akad Istishna' adalah transaksi terhadap barang dagangan dalam tanggungan yang diisyaratkan untuk mengerjakannya. ${ }^{12}$ Objek transaksinya adalah barang yang harus dikerjakan dan pekerjaannya pembuatan barang itu.

Istishna' ialah kontrak atau transaksi yang ditandatangani bersama antara pemesan dengan produsen untuk pembuatan suatu jenis barang tertentu atau suatu perjanjian jual beli dimana barang yang akan diperjualbelikan belum ada. ${ }^{13}$

Transaksi istishna' adalah transaksi yang bergerak dalam bidang pekerjaan dan barang dalam tanggungan sehingga mempunyai hukum mengikat bagi kedua belah pihak jika memenuhi rukun-rukun dan syarat-syaratnya. ${ }^{14}$

Secara etimologis Syirkah berarti ikhtilath (percampuran), yakni bercampurnya satu harta dengan harta yang lain, sehingga tidak bisa dibedakan antara keduanya. Selanjutnya, kata Syirkah itu digunakan oleh umat Islam untuk sebuah transaksi perkongsian dalam dunia bisnis. ${ }^{15}$ Dalam mendefinisikan Syirkah secara istilah syar'i, para ulama berbeda penekanan yang mengakibatkan perbedaan rumusan redaksional.

Syirkah dari segi jenisnya, dapat dibedakan kepada beberapa macam yaitu:

1. Syirkah Amla' ; yaitu dua orang atau lebih memiliki benda/harta, yang bukan disebabkan akad Syirkah. Perkongsian pemilikan ini tercipta karena warisan, wasiat, membeli bersama, diberi bersama, atau kondisi lainnya yang berakibat pemilikan satu asset oleh dua orang atau lebih. Syirkah amlak ini terbagi lagi kepada dua macam, yaitu Syirkah ikhtiyariyah dan Syirkah ijbariyah.

a. Syirkah ikhtiyariyah, yaitu Syirkah yang terjadi oleh perbuatan dua orang yang bekerjasama, seperti manakala keduanya membeli, diberi atau diwasiati lalu keduanya menerima, sehingga sesuatu tersebut menjadi hak milik bersama bagi keduanya.

b. Syirkah ijbariyah, yaitu Syirkah yang terjadi bukan oleh perbuatan dua pihak atau lebih sebagaimana Syirkah ikhtiyar di atas, tetapi mereka memilikinya secara otomatis, terpaksa dan tidak bisa mengelak (jabari), 
238 AT-TAWASSUTH: Jurnal Ekonomi Islam, Volume IV No. 2

Juli - Desember 2019: 231 - 251

seperti dua orang yang mewarisi sesuatu, sehingga kedua orang tersebut sama-sama mempunyai hak atas harta warisan tersebut.

2. Syirkah 'U kud, yaitu transaksi yang dilakukan oleh dua orang atau lebih untuk berserikat dalam permodalan dan keuntungan. Para ulama berbeda pendapat dalam membagi jenis-jenis Syirkah 'ukud. Menurut Hanabilah, Syirkah 'ukud ada 5 macam, yaitu:

a) Syirkah'inan

b) Syirkah Mufawadhah

c) Syirkah Abdan

d) Syirkah Wujuh

e) Syirkah Mudharabah

Menurut Hanafiyah Syirkah itu ada enam macam, yaitu :

a) Syirkah Amwal

b) Syirkah A'mal

c) Syirkah Wujuh

Setiap Syirkah tersebut terdiri dari dua macam Syirkah, yaitu Syirkah mufawadhah dan Syirkah 'inan. Sehingga seluruhnya berjumlah enam jenis Syirkah.

Sedangkan menurut Malikiyah dan Syafi'iyah Syirkah ada empat macam:

1. Syirkah Inan

2. Syirkah Mufawadhah

3. Syirkah Abdan

4. Syirkah Wujuh ${ }^{16}$

Para ulama sepakat bahwa Syirkah 'inan dibolehkan, Sedangkan untuk jenis Syirkah yang lain, terdapat perbedaan pendapat di kalangan para ulama. Syafi'iyah hanya membolehkan Syirkah 'inan dan Syirkah mudharabah. Hanabilah membolehkan semua jenis Syirkah kecuali Syirkah mufawadhah. Malikiyah membolehkan semua Syirkah, kecuali Syirkah wujuh dan mufawadhah.

Dari beberapa bentuk pembagian dan pengelompokkan Syirkah di atas, dengan pembagian dan pengelompokkan yang bervariasi, maka dalam hal ini peneliti menyimpulkan bahwa Syirkah 'uqud itu ada 4 (empat) macam, yaitu Syirkah 'inan, Syirkah mufawadhah, Syirkah a'mal/abdan dan Syirkah wujuh. Sedangkan mudharabah tidak dikelompokkan kedalam Syirkah, hal ini didasari 
kepada objek/kontribusi yang yang harus diserahkan oleh orang yang bersyerikat haruslah sama, sedangkan pada mudharabah kontribusinya berbeda, yang satu sebagai shahibul maal atau pemilik modal dan yang satunya lagi adalah sebagai mudharib atau pengelola. Selanjutnya penjelasan dari masing-masing Syirkah tersebut sebagai berikut:

1. Syirkah 'Inan,

Adalah kontrak antara dua orang atau lebih. Setiap pihak memberikan suatu porsi dari keseluruhan dana dan berpartisipasi dalam kerja. Kedua pihak berbagi dalam keuntungan dan kerugian sebagaimana disepakati di antara mereka. Namun porsi masing-masing pihak, baik dalam dana, hasil kerja maupun bagi hasil berbeda, sesuai dengan kesepakatan mereka. ${ }^{17}$

\section{Syirkah Mufawadhah}

Adalah dua orang atau lebih melakukan serikat bisnis dengan syarat adanya kesamaan dalam permodalan, pembagian keuntungan dan kerugian, kesamaan kerja, tanggung jawab dan beban hutang. Satu pihak tidak dibenarkan memiliki saham (modal) lebih banyak dari partnernya. Apabila satu pihak memiliki saham modal sebasar 1000 dinar, sedangkan pihak lainnya 500 dinar, maka ini bukan Syirkah mufawadhah, tapi menjadi Syirkah inan. Demikian pula aspekaspek lainnya, harus memiliki kesamaan. ${ }^{18}$

3. Syirkah 'Amal/abdan

Adalah kontrak kerja sama dua orang atau lebih untuk menerima pekerjaan secara bersama dan berbagi keuntungan dari pekerjaan itu, seperti tukang jahit, tukang besi, tukang kayu, arsirtek, dsb. Misalnya, dua pihak sepakat dan berkata, "Kita berserikat untuk bekerja dan keuntungannya kita bagi berdua". Syirkah ini sering disebut juga Syirkah abdan atau shana'iy. ${ }^{19}$

\section{Syirkah Wujuh}

Adalah kontrak bisnis antara dua orang atau lebih yang memiliki reputasi dan prestise baik, di mana mereka dipercaya untuk mengembangkan suatu bisnis tanpa adanya modal. Misalnya, mereka dipercaya untuk membawa barang dagangan tanpa pembayaran cash. Artinya mereka dipercaya untuk membeli barang-barang itu secara cicilan dan selanjutnya memperdagangkan barang tersebut untuk mendapatkan keuntungan. Mereka berbagi dalam keuntugan dan kerugian berdasarkan jaminan supplier kepada masing-masing mereka. Oleh 
karena bisnis ini tidak membutuhkan modal, maka kontrak ini biasa disebut sebagai Syirkah piutang. ${ }^{20}$

Simsarah (simsarah) adalah perantara perdagangan (orang yang menjualkan barang atau mencarikan pembeli), atau perantara antara penjual dan pembeli untuk memudahkan jual beli. ${ }^{21}$ Menurut Sayid Sabiq perantara (simsarah) adalah orang yang menjadi perantara antara pihak penjual dan pembeli guna melancarkan transaksi jual beli. ${ }^{22}$ Dengan adanya perantara maka pihak penjual dan pembeli akan lebih mudah dalam bertransaksi, baik transaksi berbentuk jasa atau berbentuk barang.

Menurut Rafiq al Mishry bahwa simsarah (makelar) adalah pedagang perantara di mana dia menjualkan barang orang lain dengan mengambil upah atas usaha yang dilakukan tanpa menanggung resiko. Dengan demikian simsarah (makelar) ialah penengah antara penjual dan pembeli untuk memudahkan jualbeli. ${ }^{23}$ Jadi Simsarah adalah perantara antara konsumen dengan pihak yang memerlukan jasa mereka yaitu produsen atau pemilik barang. Hal ini bertujuan untuk memudahkan terjadinya transaksi jual-beli dengan upah yang disepakati sebelum terjadinya akad kerja sama tersebut.

Yusuf Qardhawi berpendapat bahwa makelar bagi orang yang berasal dari luar daerah dibolehkan, karena dapat melancarkan keluar masuknya barang dari luar ke dalam daerah melalui perantara atau makelar tersebut dengan demikian mereka akan mendatangkan keuntungan bagi kedua belah pihak.

Lebih lanjut Sayyid Sabiq menjelaskan bahwa simsarah adalah sebutan bagi orang yang bekerja untuk orang lain dengan adanya imbalan upah, baik untuk keperluan menjual maupun membelikan barang. Sebutan ini juga layak dipakai untuk orang yang mencarikan (menunjukkan) orang lain sebagai partnernya sehingga pihak simsarah tersebut mendapat komisi dari orang yang menjadi parnernya. ${ }^{24}$

Simsarah adalah kosakata bahasa Persia yang telah diadopsi menjadi bahasa Arab yang berarti sebuah profesi dalam menengahi dua kepentingan atau pihak yang berbeda dengan kompensasi, baik berupa upah (ujroh) atau bonus, komisi (ji'alah) dalam menyelesaikan suatu transaksi. Adapun simsarah adalah sebutan untuk orang yang bekerja untuk orang lain sebagai penengah dengan kompensasi (upah atau bonus), baik untuk menjual maupun membeli. ${ }^{25}$ 
Berdasarkan dari penjelasan di atas bisa kita simpulkan bahwa Simsarah (makelar) adalah penengah antara penjual dan pembeli atau pemilik barang dengan pembeli untuk melancarkan sebuah transaksi dengan imbalan upah (ujroh), bonus atau komisi (ji'alah).

Apabila kita kaitkan dengan kondisi masa sekarang banyak orang yang disibukkan dengan berbagai kegiatan dan pekerjaan, sehingga ada sebagian orang tidak memiliki waktu untuk menjualkan barangnya atau sebaliknya mencarikan barang yang dia butuhkan. Sebagian orang lagi mempunyai waktu luang, mempunyai keahlian untuk memasarkan (menjualkan), namun tidak memiliki barang yang akan dijualkannya.

Untuk memudahkan kesulitan yang mereka hadapi, saat ini ada orang yang berprofesi khusus menangani hal-hal yang dikemukakan di atas, seperti biro jasa: di mana kedua belah pihak mendapat keuntungan (manfaat). Biro jasa mendapat lapangan pekerjaan dan uang jasa dari hasil pekerjaannya, sedangkan orang yang memerlukan jasa mendapatkan kemudahan, karena sudah di tangani oleh orang yang mengerti di bidang keahliannya.

Dalam hal ini pihak biro jasalah yang bisa membantu dan menyelesaikan kesulitan yang dihadapi oleh pemilik barang tersebut, selain pemilik barang dapat menyelesaikan masalahnya pihak biro jasa juga mendapat lowongan kerja sehingga pemilik barang dan biro jasa sama-sama mendapatkan keuntungan.

Simsarah berhak menerima imbalan setelah memenuhi akadnya, sedangkan pihak yang menggunakan jasa Simsarah harus segera memberikan imbalan tidak boleh menghanguskan atau menghilangkannya. Karena hal-hal seperti itu sangatlah dibenci Allah SWT.

Menurut Onno W. Purbo, "E-commerce merupakan satu set teknologi dinamis, aplikasi dan proses bisnis yang menghubungkan perusahaan, konsumen serta komunitas tertentu melalui transaksi elektronik berupa perdagangan jasa maupun informasi yang dilakukan secara elektronik., 26

Sedangkan menurut Adi Nugroho, E-commerce ialah suatu jenis dari mekanisme bisnis secara elektronik yang memfokuskan diri pada transaksi bisnis berbasis individu dengan menggunakan internet sebagai media pertukaran barang dan jasa. ${ }^{27}$ 
Pendapat lain mengatakan E-commerce adalah kegiatan-kegiatan bisnis yang menyangkut konsumen (consumers), manufaktur (manufactures), service providers dan pedagang perantara (intermediaries) dengan menggunakan jaringan-jaringan komputer (computer networks) yaitu internet. ${ }^{28}$

Terdapat berbagai definisi untuk mengungkapkan istilah E-commerce. Akan tetapi pada umumnya E-commerce merujuk pada semua transaksi komersial yang menyangkut organisasi atau individu yang didasarkan pada pemprosesan data yang didigitalisasikan termasuk teks, suara dan gambar. ${ }^{29}$

\section{Konsep Jual Beli Online Dengan Sistem Dropshipping}

Dropshipping kini menjadi model bisnis yang diminati pebisnis online baru dengan modal kecil bahkan tanpa ada modal akan memperoleh keuntungan. Dropshipping adalah suatu usaha penjualan produk tanpa harus memiliki produk apa pun. Dropshipping dapat diartikan juga suatu sistem transaksi jual beli dimana pihak Dropshipper menentukan harga barang sendiri, tanpa ada menyetok barang namun setelah mendapat pesanan barang, Dropshipper langsung membeli barang dari supplier. ${ }^{30}$

Dropshipping adalah teknik manajemen rantai pasokan di mana reseller atau retailer (pengecer) tidak memiliki stok barang. Pihak produsen atau grosir akan mengirim barang secara langsung pada pelanggan. Keuntungan didapat dari selisih harga antara harga grosir dan eceran. Tetapi beberapa reseller ada yang mendapatkan komisi yang disepakati dari penjualan yang nanti dibayarkan langsung oleh pihak grosir kepada reseller. Inilah bentuk bisnis yang banyak diminati dalam bisnis online saat ini.

Secara umum, model kerjasama antara Dropshipper dengan supplier ada 2 macam, yaitu: 1) Supplier memberikan harga ke Dropshipper, kemudian Dropshipper dapat menjual barang kepada konsumen dengan harga yang ditetapkannya sendiri, dengan memasukkan keuntungan Dropshipper. 2) Harga sejak awal sudah ditetapkan oleh supplier, termasuk besaran fee untuk Dropshipper bagi setiap barang yang terjual. Pada jenis pertama, supplier memberikan kebebasan kepada Dropshipper untuk memasarkan suatu produk dengan penetapan harga sesuai keinginan Dropshipper, biasanya tidak ada biaya 
pendaftaran serta tidak ada batas minimal pembelian. Jenis inilah yang paling mudah serta banyak digemari oleh pelaku bisnis Dropshipping. Sedangkan pada jenis kedua, umumnya ada biaya pendaftaran anggota dan terdapat batas minimal penjualan.

Dalam sistem ini, Dropshipper hanya menjadi perantara untuk konsumen dengan pihak penjual atau supplier yang sebenarnya. Dropshipper tidak pernah menyetok dan menyediakan tempat penyetokan barang melainkan hanya mempromosikan melalui toko online dengan memasang foto serta kriteria barang dan harga. Barang didapat dari jalinan kerja sama dengan pihak lain yang memiliki barang yang sesungguhnya. ${ }^{31}$ Dropshipper hanya menyediakan sarana melalui website maupun media sosial seperti Facebook, Instagram atau yang lainnya untuk pemasaran produk barang atau jasa yang akan ditawarkan dengan cara mengupload gambar atau foto produk yang dijual dengan menyebutkan beberapa ketentuan dan beberapa. spesifikasi barang yang ditawarkan seperti harga, ukuran, bahan, timbangan dan sebagainya.

Bisnis transaksi jual beli dengan sistem Dropshipping memiliki beberapa keuntungan bagi Dropshipper dibandingkan dengan sistem lainnya, yaitu: ${ }^{32}$

1) Dropshipper mendapat untung atau fee (upah) atas jasanya memasarkan barang milik supplier.

2) Tidak membutuhkan modal besar untuk menjalankan sistem ini.

3) Dropshipper tidak perlu menyediakan kantor dan gudang barang.

4) Dropshipper dapat menjalankan sistem ini. meskipun tanpa berbekal pendidikan tinggi, asalkan cakap berselancar di dunia maya

5) Dropshipper terbebas dari beban pengemasan dan distribusi produk.

6) Dropshipper dapat menjalankan usaha ini kapan pun dan di mana pun berada karena sistem ini tidak mengenal batas waktu atau ruang.

\section{Analisis Ekonomi Islam terhadap Jual Beli Dropshipping}

\section{Jual beli Dropshipping dengan Pendekatan Mashlahah Mursalah}

Secara istilah, mashlahah al-mursalah adalah suatu kemashlahatan yang tidak ditetapkan oleh syara' sesuatu hukum untuk mewujudkannya dan tidak pula terdapat suatu dalil syara' yang memerintahkan untuk 
244 AT-TAWASSUTH: Jurnal Ekonomi Islam, Volume IV No. 2

Juli - Desember 2019: 231 - 251

memperhatikannya atau mengabaikannya. Menurut Yasser Auda, maqasid merupakan merupakan ekspresi lain dari "kepentingan manusia" atau masalih. Sebagai contoh al-Juwaini yang kadang-kadang menggunakan kata maqasid dan diwaktu yang lain menyebutnya dengan masalih. ${ }^{33}$

Sedangkan al-Qarafi selalu menghubungkan maqasid dengan maslahah dengan menjelaskan bahwa "tujuan (maqshid) tidak akan benar (valid) kecuali ia mampu memberi manfaat (maslahah) dan menghindarkan dari kemudaratan (mafsadah). Sedangkan asy-Syatibi mengungkapkannya dengan "Sesungguhnya syari'at itu bertujuan mewujudkan kemaslahatan manusia di dunia dan di akhirat" dan "hukum-hukum disyari'atkan untuk kemaslahatan hamba".

Adapun yang menjadi objek al-maslahah al-mursalah adalah kejadian atau peristiwa yang perlu ditetapkan hukumnya, tetapi tidak ada satupun nash (al-Qur'an dan al-Hadits) yang dapat dijadikan dasar. Prinsip yang disepakati oleh kebanyakan pengikut mazhab yang ada dalam fikih. Menurut Imam alQarafi ath-Thusi sebagaimana yang dikutip oleh Totok Jumantoro bahwa mashlahat al-Mursalah itu sebagai dasar untuk menetapkan hukum dalam bidang muamalah sebagaimana pada praktek jual beli Dropshipping.

\section{Jual Beli Dropshipping dengan Pendekatan Maqashid Syariah}

Maqashid ditinjau dari lughawi adalah bentuk jama' dari maqshid yang berarti kesengajaan atau tujuan. Jadi dapat diartikan sebagai suatu kesulitan dari apa yang dituju atau dimaksud. Secara akar bahasa, maqashid berasal dari kata qashada, yaqshidu, qashdan, qashidun, yang berarti keinginan yang kuat, berpegang teguh, dan sengaja. Atau dapat juga diartikan dengan menyengaja atau bermaksud kepada (qashada ilaihi). Sebagaimana firman Allah SWT: 'Wa'alallahi Qashdussabili", artinya, Allah lah yang menjelaskan jalan yang lurus. Sedangkan kata syari'ah berasal dari kata syara'a as-syai yang berarti menjelaskan sesuatu. Atau diambil dari asy-syari'ah dengan arti tempat sumber air yang tidak pernah terputus dan orang datang ke sana tidak memerlukan alat. Maka al-syari'ah berarti jalan 
menuju sumber air, atau bisa dikatakan dengan jalan menuju ke arah sumber kehidupan.

Wahbah al-Zuhaili mendefinisikan maqashid syari'ah dengan maknamakna dan tujuan-tujuan yang dipelihara oleh syara' dalam seluruh hukumnya atau sebagian besar hukumnya, atau tujuan akhir dari syari'at dan rahasiarahasia yang diletakkan oleh syara' pada setiap hukumnya. ${ }^{34}$ Dengan demikian, menurut Zuhaili, maqashid syari'ah bukan hanya mengandung arti kemaslahatan umat manusia, namun juga asrar asy-syari'ah yaitu rahasiarahasia yang terdapat di balik hukum yang ditetapkan oleh syara', berupa kemaslahatan bagi umat manusia, baik di dunia maupun di akhirat.

Demikian halnya terhadap jual beli Dropshipping yang banyak memberikan kemudahan dan kemaslahatan kepada manusia.

\section{Jual Beli Dropshipping dengan Pendekatan Istihsan}

Istihsan secara bahasa adalah kata bentuk (musytaq) darialhasan (apapun yang baik dari sesuatu). Istihsan sendiri kemudian berarti kecenderungan seseorang pada sesuatu karena menganggapnya lebih baik, dan ini bisa bersifat lahiriah (hissiy) ataupun maknawiah, meskipun hal itu dianggap tidak baik oleh orang lain. ${ }^{35}$

Secara istilah, para ulama ushul mendefinisikannya dengan berbagai redaksi yang berbeda, al-Ghazali sebagaimana yang dikutip oleh Amir Syarifuddin dalam bukunya Ushul Fiqh, mengatakan bahwa istihsan adalah salah satu metode ijtihad, yaitu "apa yang dikira dalil, namun tidak termasuk dalil. Jadi merupaka sesuatu yang terbetik dalam diri seorang mujtahid, namun tidak dapat diungkapkannya dengan kata-kata.

Adapun istihsan menurut ulama Hanabilah ialah berpindahnya seorang mujtahid dari tuntutan qiyas jali (qiyas nyata) kepada qiyas khafi (qiyas samar) atau dari hukum kulli kepada hukum pengecualian, karena ada dalil yang menyebabkan ia mencela akalnya, dan dimenangkan perpindahan ini. 
Apa yang dikemukakan para ulama di atas, dipahami maksudnya bahwa apabila seorang mujtahid menghadapi suatu perkara yang tidak ada nash yang menetapkan hukumnya, sedang untuk mencari hukum terdapat dua jalan yang berbeda-beda, jalan yang satu sudah jelas dan yang lainnya masih samarsamar, yakni dapat menetapkan hukum dan dapat pula menetapkan hukum yang lain, padahal pada diri mujtahid tersebut terdapat suatu dalil yang dapat digunakan untuk mentarjihkan jalan yang samar-samar, lalu ia meninggalkan jalan yang nyata tersebut untuk menempuh jalan yang samar-samar tersebut. Demikian pula bila ia menetapkan suatu hukum, kemudian setelah ia mendapatkan dalil yang lain yang mengecualikan suatu hukum dari dalil kulli tersebut, maka ia menetapkan hukum lain yang berbeda dengan hukum yang ditetapkan oleh dalil-dalil kulli itu. Kedua jalan inilah yang dimaksud dengan istihsan. ${ }^{36}$

Maka dengan cara ini juga lah yang dapat menetapkan kepastian terhadap kebolehan Dropshipping dalam kehidupan manusia.

\section{Analisis Praktek Jual Beli Dropshipping dalam Perspektif Ekonomi Islam}

Setelah melakukan kajian teori yang berkaitan dengan beberapa transaksi jual beli serta praktek jual beli pada akad Dropshipping maka peneliti akan menganalisis praktek jual beli Dropshipping dalam perspektif ekonomi Islam.

Sebagaimana yang sudah peneliti paparkan pada pembahasan terdahulu mengenai bentuk-bentuk jual beli dan akad kerja sama, maka jual beli Dropshipping ini merupakan transaksi yang dibolehkan dalam perspektif ekonomi Islam, adapun akad yang digunakan yaitu akad kerja sama atau Syirkah dan akad simsarah.

Jual beli Dropshipping dengan menggunakan akad Syirkah ini tergolong kepada akad Syirkah wujuh, yaitu kontrak bisnis antara dua orang atau lebih yanag memiliki reputasi dan prestise baik, di mana mereka dipercaya untuk mengembangkan suatu bisnis tanpa adanya modal. Misalnya, mereka dipercaya untuk membawa barang dagangan tanpa pembayaran cash. Artinya mereka dipercaya untuk membeli barang-barang itu secara cicilan dan selanjutnya 
memperdagangkan barang tersebut untuk mendapatkan keuntungan. Mereka berbagi dalam keuntugan dan kerugian berdasarkan jaminan supplier kepada masing-masing mereka. Oleh karena bisnis ini tidak membutuhkan modal, maka kontrak ini biasa disebut sebagai Syirkah piutang. ${ }^{37}$

Jual beli Dropshipping ini,di samping menggunakan akad Syirkah wujuh, juga dapat dipersamakan dengan akad yang dikenal dengan simsarah, yaitu akad jual beli dengan cara adanya perantara / penengah antara penjual dan pembeli atau pemilik barang dengan pembeli untuk melancarkan sebuah transaksi dengan imbalan upah (ujroh), bonus atau komisi (ji'alah).

Apabila kita kaitkan dengan kondisi masa sekarang banyak orang yang disibukkan dengan berbagai kegiatan dan pekerjaan, sehingga ada sebagian orang tidak memiliki waktu untuk menjualkan barangnya atau sebaliknya mencarikan barang yang dia butuhkan. Sebagian orang lagi mempunyai waktu luang, mempunyai keahlian untuk memasarkan (menjualkan), namun tidak memiliki barang yang akan dijualkannya.

\section{Kesimpulan}

Berdasarkan hasil penelitian yang telah dilakukan mengenai analisis praktek jual beli Dropshipping Dalam Perspektif Ekonomi Islam maka peneliti menyimpulkan :

1. Jual beli Dropshipping ini merupakan jual beli dengan skema yang dilakukan oleh penjual dan pembeli, di mana si penjual adalah sebagai perantara dalam jual beli Dropshipping ini, karena si penjual tidak memiliki barang, tetapi menjualkan barang supplier kepada pembeli disebabkan adanya saling mempercayai diantara pihak-pihak yang terkait. Akad ini dikenal dengan simsarah (Akad jual beli dengan perantara) dan juga dapat disebut dengan syirkah wujuh (kerja sama karena saling mempercayai).

2. Dalam pandangan ekonomi Islam jual beli Dropshipping ini merupakan suatu transaksi untuk mewujudkan kesejahteraan manusia yang sesuai dengan Maqashid Syariah yaitu terciptanya kemaslahatan dan terhindar dari kemudharatan. Maqashid Syariah dapat memberikan pola pemikiran yang 
rasional dan dapat merespon kemajuan dalam berbisnis yang terus berkembang.

\section{Saran}

Berangkat dari pemaparan yang telah dilakukan maka peneliti memberikan saran sebagai berikut :

1. Disarankan kepada pelaku Dropshipper dapat melakukan tindakan wirausaha mandiri sehingga dapat menciptakan suatu lapangan pekerjaan baru tanpa harus memikirkan keterbatasan terhadap jarak, waktu ataupun modal.

2. Disarankan kepada masyarakat agar lebih meningkatkan kemampuannya untuk memanfaatkan kemajuan teknologi secara maksimal. Dalam hal ini untuk dapat melakukan kegiatan transaksi secara online.

\section{Catatan}

${ }^{1}$ Muhammad Ismail, DK. Menggagas Bisnis Islam (Jakarta: Gema Insani Press, 2002), h. 93.

${ }^{2}$ Andri Donnal Putera, 'J umlah Pembeli Online Indonesia Capai 11,9 Persen Dari Populasi, Kompas.Com,2018<https://ekonomi.kompas.com/read/2018/09/07/164100326/jumlahpembeli-online-indonesia-capai-119-persen-dari-populasi> [accessed 22 February 2019]. 2013), h.15.

${ }^{3}$ Arto Soebiantoro, Merek Indonesia Harus Bisa, (Jakarta: PT Elex Media Komputindo,

${ }^{4}$ Ahmad Syafii, Step By Step Bisnis Dropshipping dan Reseller (Jakarta: PT Elex Media Komputindo, 2013), h. 2.

${ }^{5}$ Hendi Suhendi, Fiqh Muamalah, (Jakarta: PT Raja Grafindo Persada, 2002), h.1.

${ }^{6}$ Ibid., h. 2

${ }^{7}$ Adiwarman A. Karim, Bank Islam: Analisis Fiqih dan Keuangan, h. 70.

${ }^{8}$ Wahbah az-Zuhaili, Fiqih Islam Wa Adillatuhu, Jilid V (Jakarta: Darul Fikir Gema Insani, 2011), h. 366.

${ }^{9}$ Ibnu Rusyd, Hidayatul Mujtahid, Jilid III, (Jakarta: Pustaka Amani, 2007), h. 45.

${ }^{10}$ Departemen Agama RI, Al-Quran dan Terjemahnya, h. 69.

${ }^{11}$ Al-Kahlani, Subulussalam, Jilid III (Bandung: Dahlan, tt), h. 4.

12 Abdullah bin Muhamad Ath-Thayyar, "Ensiklopedia Fiqih Muamalah Dalam Pandangan 4 Mahzab,' Maktabah Al-Hanif, No.190 (2004): h.143, review buku Al- Khaisani, Bada'I Ash-Shana'I Juz VI , h. 2677.

\footnotetext{
${ }^{13}$ Wahbah Az-Zuhaili, Fiqih Islam Wa Adillatuhu, h. 268.

${ }^{14}$ Ibid, h. 147.
} 
${ }^{15}$ Wahbah Az-Zuhaily, Al-Fiqh al-Islami wa Adillatuhu, Juz IV, (Beirut: Darul Fikri, 1989), h. 387.

${ }^{16}$ Ibid.,

${ }^{17}$ Muhammad bin Ibrahim al- Musa, Syirkah al- Asykhash baina asy-Syari'ah wa alQanun, (Saudi Arabiya: Dar at- Tadmurayyah, 2011), h. 150.

${ }^{18}$ Ibid., 165.

${ }^{19}$ Ibid., 178.

${ }^{20}$ Ibid., h. 185.

${ }^{21}$ M. Ali, Hasan, Berbagai Macam Transaksi dalam Islam, (figh muamalat), ed. 1., cet.2,( Jakarta: PT Raja Grafindo Persada, 2004), h. 289.

${ }^{22}$ Sayyid Sabiq, Fiqh Sunnah, jilid 3, (Beirut: Dar al Kitab al-Araby, 1987), h. 125.

${ }^{23}$ Rafiq Yunus al Mishry, Fiqh Muamalah al Maliyah, (Damsyiq: Darul Qalam, 2005), h. 195.

${ }^{24}$ Sayyid Sabiq, Fiqh Sunnah, jilid 3, h. 126.

${ }^{25}$ Rafiq Yunus al Mishry, Fiqh Muamalah al Maliyah. h. 195.

${ }^{26}$ Onno W.Purbo dan Aang Arif Wahyudi, Mengenal E-commerce, (Jakarta: Elex Media Komputindo, 2000), h.13.

${ }^{27}$ Adi Nugroho, E-commerce Memahami Perdagangan di Dunia Maya, cet.I (Bandung: Informatika, 2006), h. 9.

${ }^{28}$ Barkatulloh dan Teguh Prasetyo, Bisnis E-commerce: Studi Sistem Keamanan dan Hukum di Indonesia, cet.1, (Yogyakarta: Pustaka Pelajar, 2005), h. 5.

29 Haris Faulidi Asnawi, Transaksi Bisnis E-commerce Perspektif Islam, cet.1, (Yogyakarta:Magista Insania Press, 2004), h. 29.

${ }^{30}$ Derry Iswidharmanjaya, Dropshipping Cara Mudah Bisnis Online, (Jakarta: PT Elex Media Komputindo, 2012), h. 5.

${ }^{31}$ Feri Sulianta, Terobosan Berjualan Online ala Dropshipping, (Yogyakarta: Penerbit Andi, 2014), h. 2.

${ }^{32}$ Muhammad Arifn Badri, "J ual Beli sistem Dropshipping", dalam Majalah Al-Furqon, No. 156 Ed. 9 Th ke-14_1436H/2015M. 2007), h.2.

${ }^{33}$ Yasser Auda. Maqasid al-Shariah as Philosophy of Islamic Law. (Herndon: IIIT,

${ }^{34}$ Wahbah al-Zuhaili. Ushul al-Fiqh al-Islami, Juz II (Mesir: Dar al-Fikr, 2008), h. 307.

${ }^{35}$ Ibnu Manzhur, lisan al- Arab, jld. 13, (Beirut: Dar al- Shodir, th), h. 117.

${ }^{36}$ Mukhtar Yahya dan Fathurrahman, Dasar-dasar Pembinaan Hukum Fiqh Islami, 1997, (Bandung: al- Ma'arif), h. 101.

${ }^{37}$ Ibid., h. 185. 
250 AT-TAWASSUTH: Jurnal Ekonomi Islam, Volume IV No. 2

Juli - Desember 2019: 231 - 251

\section{DAFTAR PUSTAKA}

al Mishry, Rafiq Yunus, Fiqh Muamalah al Maliyah, Damsyiq: Darul Qalam. 2005.

al- Musa, Muhammad bin Ibrahim, Syirkah al- Asykhash baina asy-Syari'ah wa al-Qanun,. Saudi Arabiya: Dar at- Tadmurayyah. 2011.

Al-Kahlani, Subulussalam, Jilid III. Bandung: Dahlan.

Asnawi, Haris Faulidi, Transaksi Bisnis E-commerce Perspektif Islam, cet.1, Yogyakarta:Magista Insania Press, 2004.

Ath-Thayyar, Abdullah bin Muhamad, Ensiklopedia Fiqih Muamalah Dalam Pandangan 4 Mahzab,' Maktabah Al-Hanif, No.190 (2004): h.143, review buku Al- Khaisani, Bada'I Ash-Shana'I Juz VI.

Auda, Yasser. Maqasid al-Shariah as Philosophy of Islamic Law. Herndon: IIIT. 2007.

Az- Zuhaili, Wahbah. Fiqih Islam Wa Adillatuhu, Jilid V. Jakarta: Darul Fikir Gema Insani. 2011.

Badri, Muhammad Arifn, "J ual Beli sistem Dropshipping", dalam Majalah AlFurqon, No. 156 Ed. 9 Th ke-14_1436H/2015M.

Barkatulloh dan Teguh Prasetyo, Bisnis E-commerce: Studi Sistem Keamanan dan Hukum di Indonesia, cet.1, Yogyakarta: Pustaka Pelajar, 2005,

Departemen Agama RI, Al-Quran dan Terjemahnya.

Iswidharmanjaya, Derry, Dropshipping Cara Mudah Bisnis Online, Jakarta: PT Elex Media Komputindo, 2012.

Karim, Adiwarman A., Bank Islam: Analisis Fiqih dan Keuangan.

M. Ali, Hasan, Berbagai Macam Transaksi dalam Islam, (figh muamalat), ed. 1., cet.2,( Jakarta: PT Raja Grafindo Persada, 2004), h. 289.

Muhammad Ismail, DK. Menggagas Bisnis Islam (Jakarta: Gema Insani Press, 2002), h. 93.

Nugroho, Adi, E-commerce Memahami Perdagangan di Dunia Maya, cet.I Bandung: Informatika. 2006.

Purbo, Onno W. dan Aang Arif Wahyudi, Mengenal E-commerce, Jakarta: Elex Media Komputindo. 2000. 
Putera, Andri Donnal, 'J umlah Pembeli O nline Indonesia Capai 11,9 Persen Dari Populasi,

Kompas.Com,2018<https://ekonomi.kompas.com/read/2018/09/07/1641

00326/jumlah-pembeli-online-indonesia-capai-119-persen-dari-

populasi> [accessed 22 February 2019].

Rusyd, Ibnu, Hidayatul Mujtahid, Jilid III. Jakarta: Pustaka Amani. 2007.

Sabiq, Sayyid, Fiqh Sunnah, jilid 3. Beirut: Dar al Kitab al-Araby, 1987.

Soebiantoro, Arto, Merek Indonesia Harus Bisa, Jakarta: PT Elex Media Komputindo. 2013.

Sulianta, Feri, Terobosan Berjualan Online ala Dropshipping, Yogyakarta: Penerbit Andi, 2014.

Syafii, Ahmad, Step By Step Bisnis Dropshipping dan Reseller. Jakarta: PT Elex Media Komputindo. 2013. 